\title{
PENERAPAN MODEL PEMBELAJARAN THINK PAIR SHARE UNTUK MENINGKATKAN HASIL BELAJAR SISWA PADA MATA PELAJARAN BAHASA INGGRIS SISWA MTs NEGERI BINJAI
}

\author{
Dra. Hj. Nur Khairani \\ MTs Negeri Binjai Kota Binjai
}

\begin{abstract}
ABSTRAK
Penelitian ini bertujuan untuk mendeskripsikan proses penerapan model pembelajaran think pair share untuk meningkatkan aktivitas siswa MTs Negeri Binjai dan mendeskripsikan hasil belajar bahasa inggris siswa sebelum dan sesudah penerapan model pembelajaran think pair share siswa MTs Negeri Binjai. Penelitian ini dilakukan dalam 2 (dua) siklus, yang terdiri dari 4 langkah yaitu perencanaan, tindakan, pengamatan dan refleksi. Tiap siklus terdiri dari 2 pertemuan, dengan indikator yang hendak dicapai yaitu kemampuan belajar siswa meningkat setelah dilakukannya sebuah tindakan. Berkaitan dengan hal tersebut, maka pada prosedur penelitian ini disajikan kegiatan pra tindakan dan kegiatan pelaksanaan tindakan. Kegiatan pelaksanaan tindakan memuat : Perencanaan tindakan, pelaksanaan tindakan, tahapan pengamatan, tahap refleksi. Rata-rata hasil belajar siswa pada tes siklus I sebesar 71,75, sedangkan rata-rata hasil belajar siswa pada tes siklus II adalah 88, dan terjadi peningkatan sebesar 16,25. Begitupun juga dengan ketuntasan belajar siswa yang mengalami peningkatan hingga $42,5 \%$, dengan rincian ketuntasan belajar siswa pada siklus I adalah $37,5 \%$ dan ketuntasan belajar siswa pada siklus II adalah $80 \%$. disimpulkan bahwa dengan meningkatnya aktivitas peneliti dalam menerapkan penggunaan media gambar dari siklus I ke siklus II dan kegiatan aktivitas siswa dari siklus 1 ke siklus II maka menjadikan kemampuan kosa kata Bahasa Inggris siswa mengalami peningkatan. Hal ini menunjukkan penerapan model pembelajaran Think Pair Share dapat meningkatkan kemampuan Bahasa Inggris siswa kelas kelas VIl MTs Negeri Binjai.

Kata kunci : model pembelajaran think pair share, hasil belajar
\end{abstract}

\section{PENDAHULUAN}

Pendidikan adalah usaha sadar dan terencana untuk mewujudkan suasana belajar dan proses pembelajaran agar peserta didik secara aktif mengembangkan potensi dirinya untuk memiliki kekuatan spiritual keagamaan, pengendalian diri, kepribadian, kecerdasan, akhlak mulia, serta keterampilan yang diperlukan dirinya, masyarakat, bangsa, dan Negara.

Pada hakikatnya pendidikan merupakan sebuah proses interaksi antara guru dengan peserta didik untuk mencapai tujuan pendidikan yang berlangsung dalam lingkungan terientu. Guru adalah pendidik profesional dengan tugas utama mendidik, mengajar, membimbing, mengarahkan, melatih, menilai, dan mengevaluasi peserta didik.

Menurut Nana Syaodih S. guru adalah manusia yang memiliki kepribadian sebagai individu dengan memiliki tugas utama sebagai pendidik, pengajar, dan pembimbing. Tugas 
utama sebagai pendidik adalah membantu mendewasakan anak baik secara psikologis, sosial, dan moral. Tugas guru sebagai pengajar adalah membantu perkembangan intelektual, afektif dan psikomotor, melalui penyampaian pengetahuan, pemecahan masalah, latihanlatihan afektif dan keterampilan. Secara umum peserta didik dapat dimaknai individu yang terlibat dalam sebuah aktifitas pendidikan dengan segala hak dan kewajibannya.

Sementara itu, ada dual hal yang saling terintegrasi antara guru dengan peserta didik, yaitu mengajar dan belajar. Menurut Nasution (2000: 4), mengajar adalah suatu aktivitas mengorganisasi atau mengatur lingkungan sebaikbaiknyadanmenghubungkannyadengan a nak sehingga terjadi proses belajar.

Belajar menurut Cronbach dalam Kunandar adalah "Learning is shown by a change in behavior as a result of experience" (Belajar adalah perubahan tingkah laku sebagai hasil pengalaman). Dari pendapat tersebut dapat disimpulkan bahwa belajar dapat berhasil jika dalam proses belajar mengajar tercipta suasana kelas yang dapat memberikan gairah dan motivasi peserta didik untuk belajar.

Guru sebagai salah satu komponen dalam proses belajar mengajar merupakan pemegang peran yang sangat penting, karena guru bukan saja penyampai materi tetapi sebagai central pembelajaran. Sebagai pengatur sekaligus pelaku dalam proses belajar mengajar. Karena itu sangat dibutuhkan model pembelajaran yang variatif untuk mencapai keberhasilan dari proses belajar mengajar.

Model pembelajaran dikembangkan dari adanya perbedaan karakteristik siswa yang bervariasi. Karena siswa memiliki berbagai karakteristik kepribadian, kebiasaan-kebiasaan, cara belajar yang bervariasi antara individu satu dengan yang lain, maka model pembelajaran tidak terpaku hanya pada model tertentu. Model pembelajaran adalah kerangka konseptual yang melukiskan pola atau prosedur secara sistematis dalam mengorganisasikan pembelajaran yang berfungsi sebagai pedoman bagi para pengajar dalam merencanakan dan melaksanakan pembelajaran.

Dalam mengajarkan suatu pokok bahasan atau materi tertentu harus dipilih model pembelajaran yang paling sesuai dengan tujuan yang akan dicapai. Oleh karena itu, dalam memilih suatu model pembelajaran harus memiliki pertimbangan-pertimbangan. Misalnya materi pelajaran, tingkat perkembangan kognitif siswa dan sarana atau fasilitas yang tersedia, sehingga tujuan pembelajaran yang telah ditetapkan dapat tercapai.

Dari beberapa model pembelajaran yang telah dipelajari oleh peneliti, maka peneliti mengambil salah satu model pembelajaran kooperatif tipe Think Pair Share dalam pembelajaran Bahasa Inggris. Dengan harapan bahwa setelah melakukan penelitian ini, model pembelajaran Think Pair Share ini dapat diterapkan oleh guru dalam proses belajar mengajar sehingga dapat meningkatkan hasil belajar siswa.

Hasil belajar merupakan salah satu faktor keberhasilan peserta didik. Melalui hasil belajar siswa, guru dapat mengetahui sejauh mana kemampuan siswa dalam memahami materi yang disampaikan guru, sehingga guru perlu mengetahui hasil belajar siswa di kelas. Hasil belajar siswa merupakan tolak ukur bagi guru dalam menentukan tindakan yang tepat dan bermanfaat bagi suatu proses pembelajaran karena peran guru bukan hanya melaksanakan pembelajaran saja, tetapi guru perlu mengetahui bagaimana hasil belajar siswa dan faktor yang melatar belakanginya.

Faktor yang dianggap menjadi akar permasalahan kurangnya hasil belajar siswa dalam memahami bahasa Inggris. Sebagaimana yang dikemukakan di atas rendahnya hasil 
belajar siswa disebabkan oleh dua faktor, yaitu faktor eksternal dan faktor internal.

Faktor Eksternal yang dianggap turut mempengaruhi rendahnya hasil belajar siswa adalah faktor Lingkungan Keluarga, Lingkungan Sekolah, dan Lingkungan Masyarakat, sedangkan faktor internalnya dipengaruhi oleh faktor dari dalam diri siswa, yakni keadaan dan kondisi jasmani dan rohani siswa. Faktor intern terdiri dari : Faktor jasmaniah (kesehatan dan cacat tubuh), Faktor psikologis (intelegensi, perhatian, minat, bakat, motif, kematangan dan persiapan), Faktor kelelahan.

Salah satu pelajaran yang dipelajari para siswa dalam pendidikan Madrasah Tsanawiyah adalah pelajaran bahasa Inggris yang banyak cenderung dipandang sebagai mata pelajaran yang sulit, membosankan dan tidak disukai oleh sebagian siswa, karena bahasa Inggris adalah pelajaran yang banyak dengan kosa kata yang sulit diterjemahkan oleh siswa, apalagi dalam pengucapannya. Agar siswa tidak bosan dan siswa senang dalam belajar bahasa Inggris, maka Guru harus memiliki kreativitas yang tinggi dalam mengajar untuk menciptakan kondisi yang menyenangkan dan tidak monoton sehingga siswa merasa senang dan menyukai pelajaran bahasa Inggris serta siswa dapat lebih aktif bertanya dan mengemukakan gagasannya.

Oleh karena itu, jika dalam proses pembelajarannya siswa kurang diaktifkan atau siswa kurang berperan maka pembelajaran itu hanya sedikit saja yang dapat diserap oleh siswa, dengan demikian hasil belajar siswa tidak memuaskan seperti yang diharapkan. Ketika siswa pasif atau hanya menerima dari guru, ada kecenderungan untuk cepat melupakan apa yang telah diberikan. Maka diperlukan perangkat tertentu untuk dapat mengikuti informasi yang baru saja diterima dari guru yaitu dengan menunjukkan berbagai macam gambar, kemudian siswa diharap dapat menyebutkan gambar tersebut dengan menggunakan bahasa Inggris.

Setiap kali siswa disuruh memahami materi-materi atau istilah-istilah yang terdapat dalam pelajaran bahasa Inggris tentang menyebutkan gambar-gambar dengan menggunakan bahasa Inggris sesekali mendapat kesulitan dalam mengartikan dan memahami cara menyebutkan gambar-gambar tersebut dengan menggunakan bahasa Inggris. Kesulitan siswa ini menurut pengamatan peneliti adalah kurangnya kemampuan siswa dalam memahami pelajaran bahasa Inggris yang dimiliki oleh para siswa, disamping itu adalah kurangnya mereka berlatih dan belajar dalam memahami pelajaran bahasa Inggris bentuk pengucapan maupun terjemahannya, juga dalam mengerjakan tugas-tugas yang ada dalam LKS maupun dalam buku pelajaran bahasa Inggris.

Berdasarkan latar belakang yang telah dikemukakan di atas peneliti sebagai guru perlu mengadakan suatu Penelitian Tindakan Kelas (PTK) yang berjudul ; "Penerapan Model Pembelajaran Think Pair Share untuk meningkatkan hasil belajar siswa pada mata pelajaran Bahasa Inggris Siswa MTs Negeri Binjai”.

\section{METODOLOGI PENELITIAN}

Penelitian ini dilakukan di Madrasah Tsanawiyah Negeri Binjai (MTs Negeri Binjai) yang beralamat di Jalan Pekan Baru No. 2A Binjai. Waktu Pelaksanaan pada bulan September sampai dengan Oktober. Subyek penelitian dalam penelitian ini adalah siswa kelas VII MTs Negeri Binjai, dengan jumlah siswa 40 orang.

Proses pelaksanaan penelitian tindakan kelas ini didesain model dari Kemmis \& Mc. 
Taggart yang perangkatnya terdiri atas empat komponen, yaitu planning (perencanaan), acting (tindakan), observing (pengamatan), dan reflecting (refleksi).

Penelitian ini dilakukan dalam 2 (dua) siklus, yang terdiri dari 4 langkah yaitu perencanaan, tindakan, pengamatan dan refleksi. Tiap siklus terdiri dari 2 pertemuan, dengan indikator yang hendak dicapai yaitu kemampuan belajar siswa meningkat setelah dilakukannya sebuah tindakan. Berkaitan dengan hal tersebut, maka pada prosedur penelitian ini disajikan kegiatan pra tindakan dan kegiatan pelaksanaan tindakan. Kegiatan pelaksanaan tindakan memuat : Perencanaan tindakan, pelaksanaan tindakan, tahapan pengamatan, tahap refleksi.

\section{Kegiatan Pra Tindakan}

Dalam kegiatan ini peneliti melaksanakan studi pendahuluan terlebih dahulu tentang kondisi sekolah yang akan diteliti. Pada kegiatan pra tindakan ini peneliti juga melaksanakan beberapa kegiatan lain, diantaranya :
a. Menentukan subjek penelitian
b. Menentukan sumber data
c. Membuat soal tes awal (pre test)
d. Melakukan tes awal
e. Menentukan kriteria keberhasilan

\section{Kegiatan Pelaksanaan Tindakan}

Sesuai dengan rancangan penelitian, penelitian tindakan ini dilaksanakan dalam dua siklus.

\section{a. Siklus 1}

1) Perencanaan tindakan

Perencanaan tindakan dalam siklus kesatu disusun berdasarkan hasil observasi kegiatan pra tindakan. Rancangan tindakan ini disusun dengan mencakup beberapa antara lain:
- Menyiapkan Rencana Pelaksanaan Pembelajaran (RPP)

- Menyiapkan Post Tes Siklus kesatu

- Menyiapkan lembar observasi kemampuan guru dan aktivitas siswa.

- Menyiapkan catatan lapangan.

2) Pelaksanaan

Dalam tahap pelaksanaan tindakan ini merupakan langkah pelaksanaan yang telah disusun dalam rencana tindakan kesatu.

3) Observasi

Observasi ini dilakukan bersamaan dengan pelaksanaan tindakan kesatu. Tujuan diadakan observasi ini adalah untuk mendata, menilai dan mendokumentasikan semua indikator baik proses maupun perubahan yang terjadi sebagai akibat dari tindakan yang direncanakan. Kegiatan ini meliputi pengamatan terhadap perencanaan pembelajaran, pelaksanaan tindakan kesatu, sikap siswa dalam mengikuti proses pembelajaran. Kegiatan guru dan siswa dalam proses pembelajaran ini diamati dengan menggunakan instrument yang telah dipersiapkan sebelumnya. Untuk selanjutnya data hasil observasi tersebut dijadikan dasar untuk menyusun perencanaan tindakan berikutnya.

4) Refleksi

Refleksi ini dilakukan pada akhir siklus kesatu. Tujuan dan kegiatan yang dilakukan antara lain: (a) menganalisa tindakan siklus kesatu, (b) mengevaluasi

hasil dari tindakan kesatu, (c) melakukan pemaknaan dan penyimpulan data yang diperoleh.

b. Siklus I1

1) Perencanaan tindakan

Perencanaan tindakan siklus kedua ini disusun berdasarkan refleksi hasil observasi pembelajaran pada siklus kesatu. Perencanaan tindakan ini 
dipusatkan kepada sesuatu yang belum dapat terlaksana dengan baik pada tindakan siklus kesatu.

2) Pelaksanaan

Dalam tahap pelaksanaan ini merupakan langkah pelaksanaan yang telah disusun dalam rencana tindakan kedua.

3) Observasi

Kegiatan observasi ini meliputi pengamatan terhadap perencanaan pembelajaran, pelaksanaan tindakan kedua, sikap siswa dalam mengikuti proses pembelajaran.

4) Refleksi

Refleksi ini dilakukan pada akhir siklus kedua. Tujuan dan kegiatan yang dilakukan antara lain:

a) Menganalisa tindakan siklus kesatu

b) Mengevaluasi hasil dari tindakan kesatu

c) Melakukan pemaknaan dan penyimpulan data yang diperoleh

Hasil dari refleksi siklus kedua ini dijadikan dasar dalam penyusunan laporan hasil penelitian. Selain itu juga digunakan peneliti sebagai bahan pertimbangan apakah kriteria yang ditetapkan sudah tercapai atau belum. Sesuai kriteria yang ditentukan, ada 2 kriteria keberhasilan yang ditetapkan dalam penelitian ini yaitu kriteria keberhasilan proses pembelajaran dengan menerapkan model pembelajaran Think Pair Share sebesar 75\% (kriteria cukup) dan kriteria keberhasilan hasil belajar siswa yaitu $75 \%$ siswa mendapat nilai minimal 70 .

Jika indikator tersebut telah tercapai maka siklus tindakan berhenti. Akan tetapi apabila indikator tesebut belum tercapai pada siklus tindakan, maka peneliti mengulang siklus tindakan dengan memperbaiki kinerja pembelajaran pada tindakan berikutnya sampai berhasi. Secara umum, tahap-tahap penelitian tindakan siklus II sama dengan siklus I. Hanya yang membedakan adalah perbaikan-perbaikan rancangan pembelajaran yang berdasarkan tindakan pada siklus I yang dirasa kurang maksimal.

\section{HASIL PENELITIAN DAN PEMBAHASAN}

\section{SIKLUS I}

Pada siklus I ini dilakukan untuk mengetahui sejauh mana kemampuan siswa dalam memahami kosa kata pada materi Family Life dan siklus II dilaksanakan untuk mengetahui adanya peningkatan hasil belajar siswa setelah menerapkan model pembelajaran Think Pair Share.

Tabel 1. Hasil Pengamatan Aktivitas Peneliti Pada Siklus I

\begin{tabular}{|c|c|c|c|c|c|}
\hline \multirow{2}{*}{ Tahap } & \multirow{2}{*}{ Indikator } & \multicolumn{2}{|c|}{ Pengamat I } & \multicolumn{2}{|c|}{ Pengamat II } \\
\hline & & Nilai & Deskriptor & Nilai & Deskriptor \\
\hline 1 & 2 & 3 & & 4 & \\
\hline \multirow{3}{*}{ Awal } & $\begin{array}{l}\text { Melakukan } \\
\text { aktifitas } \\
\text { keseharian }\end{array}$ & 5 & Semua & 5 & Semua \\
\hline & $\begin{array}{l}\text { Menyampaikan } \\
\text { tujuan } \\
\text { pembelajaran }\end{array}$ & 4 & $\mathrm{a}, \mathrm{b}, \mathrm{dan} \mathrm{c}$ & 4 & $\mathrm{a}, \mathrm{b}$, dan $\mathrm{c}$ \\
\hline & $\begin{array}{l}\text { Mengingatkan } \\
\text { pengetahuan } \\
\text { awal }\end{array}$ & 4 & $\mathrm{a}, \mathrm{b}, \mathrm{dan} \mathrm{c}$ & 3 & $\mathrm{~b}$ dan $\mathrm{c}$ \\
\hline \multirow{4}{*}{ Inti } & $\begin{array}{l}\text { Menyampaikan } \\
\text { materi dan } \\
\text { pentingnya } \\
\text { materi }\end{array}$ & 3 & $a$, dan $b$ & 4 & $a, b$, dan d \\
\hline & $\begin{array}{l}\text { Melakukan } \\
\text { listen and repeat }\end{array}$ & 5 & Semua & 5 & Semua \\
\hline & \begin{tabular}{l}
\multicolumn{2}{l}{ Menyediakan } \\
sarana dan \\
prasarana
\end{tabular} & 4 & $\mathrm{a}, \mathrm{b}, \mathrm{dan} \mathrm{c}$ & 4 & $\mathrm{a}, \mathrm{b}$, dan $\mathrm{c}$ \\
\hline & $\begin{array}{l}\text { Meminta siswa } \\
\text { memahami } \\
\text { tugas }\end{array}$ & 3 & $\mathrm{~b}$ dan $\mathrm{c}$ & 4 & $\mathrm{~b}, \mathrm{c}$, dan $\mathrm{d}$ \\
\hline \multirow{4}{*}{$\begin{array}{l}\text { Akhi } \\
\text { r }\end{array}$} & $\begin{array}{l}\text { Merespon } \\
\text { pembelajaran }\end{array}$ & 4 & $\mathrm{a}, \mathrm{b}, \mathrm{dan} \mathrm{c}$ & 4 & $\mathrm{a}, \mathrm{b}$, dan $\mathrm{c}$ \\
\hline & $\begin{array}{l}\text { Melakukan } \\
\text { evaluasi }\end{array}$ & 5 & Semua & 5 & semua \\
\hline & $\begin{array}{l}\text { Mengakhiri } \\
\text { pembelajaran }\end{array}$ & 4 & $\mathrm{~b}, \mathrm{c}$ dan $\mathrm{d}$ & 4 & $\mathrm{~b}, \mathrm{c}$ dan $\mathrm{d}$ \\
\hline & Jumlah Skor & 41 & & 42 & \\
\hline
\end{tabular}


Berdasarkan tabel di atas, ada beberapa hal yang tidak dilakukan peneliti meskipun demikian secara umum kegiatan peneliti sudah sesuai rencana yang ditetapkan pada lembar observasi tersebut. Nilai yang diperoleh pengamat I adalah 41 dan nilai yang diperoleh dari pengamat Il adalah 42 sedang nilai maksimal 50. Sehingga rata-rata nilai adalah $\frac{41+42}{2}=41,5$. Jika nilai akhir prosentase yang didapat adalah $\frac{41,5}{50} \times 100 \%=83 \%$. Sesuai taraf keberhasilan tindakan yang telah ditetapkan, yaitu

a. $90 \% \leq \mathrm{NR} \leq 100 \%$ : sangat baik

b. $80 \% \leq \mathrm{NR} \leq 90 \%$ : baik

c. $70 \% \leq \mathrm{NR} \leq 80 \%$ : cukup

d. $60 \% \leq \mathrm{NR} \leq 70 \%$ : kurang

e. $50 \% \leq \mathrm{NR} \leq 60 \%$ : kurang sekali

Maka taraf keberhasilan aktivitas peneliti berada pada kategori baik.

Adapun hasil pengamatan yang dilakukan oleh kedua pengamat terhadap aktivitas siswa selama kegiatan pembelajaran pada siklus I dapat dilihat pada tabel berikut :

Tabel 2. Hasil Pengamatan Aktivitas Siswa Pada Siklus I

\begin{tabular}{|c|c|c|c|c|c|}
\hline \multirow{2}{*}{ Tahap } & \multirow{2}{*}{ Indikator } & \multicolumn{2}{|c|}{ Pengamat I } & \multicolumn{2}{|c|}{ Pengamat II } \\
\hline & & Nilai & Deskriptor & Nilai & Deskriptor \\
\hline 1 & 2 & 3 & & 4 & \\
\hline \multirow{3}{*}{ Awal } & $\begin{array}{l}\text { Melakukan } \\
\text { aktifitas } \\
\text { keseharian }\end{array}$ & 5 & Semua & 5 & Semua \\
\hline & $\begin{array}{l}\text { Menyampaika } \\
\mathrm{n} \text { tujuan } \\
\text { pembelajaran }\end{array}$ & 3 & $a$, dan $b$ & 3 & $\mathrm{a}, \mathrm{dan} \mathrm{b}$ \\
\hline & $\begin{array}{l}\text { Keterlibatan } \\
\text { dalam } \\
\text { pembangkitan } \\
\text { pengetahuan } \\
\text { awal } \\
\end{array}$ & 4 & $\begin{array}{l}\mathrm{a}, \mathrm{b}, \mathrm{dan} \\
\mathrm{c}\end{array}$ & 4 & $\mathrm{a}, \mathrm{b}$ dan $\mathrm{c}$ \\
\hline Inti & $\begin{array}{l}\text { Menyimak } \\
\text { penjelasan } \\
\text { materi }\end{array}$ & 4 & $\begin{array}{l}a, b, \text { dan } \\
c\end{array}$ & 4 & $\begin{array}{l}\mathrm{a}, \mathrm{b}, \mathrm{dan} \\
\mathrm{d}\end{array}$ \\
\hline
\end{tabular}

\begin{tabular}{|c|c|c|c|c|c|}
\hline & $\begin{array}{l}\text { Keterlibatn } \\
\text { dalam listen } \\
\text { and repeat }\end{array}$ & 5 & Semua & 5 & Semua \\
\hline & $\begin{array}{l}\text { Memanfaatka } \\
\text { n sarana dan } \\
\text { prasarana } \\
\text { yang tersedia }\end{array}$ & 4 & $\begin{array}{l}a, b, \text { dan } \\
c\end{array}$ & 4 & $\begin{array}{l}\mathrm{a}, \mathrm{b}, \mathrm{dan} \\
\mathrm{c}\end{array}$ \\
\hline \multirow{4}{*}{ Akhir } & $\begin{array}{l}\text { Merespon } \\
\text { kegiatan }\end{array}$ & 4 & $\begin{array}{l}\text { a, c, dan } \\
\text { d }\end{array}$ & 3 & $\mathrm{a}, \mathrm{c}$ dan $\mathrm{d}$ \\
\hline & $\begin{array}{l}\text { Melakukan } \\
\text { evaluasi }\end{array}$ & 4 & $\begin{array}{l}\text { a, c, dan } \\
\text { d }\end{array}$ & 4 & Semua \\
\hline & $\begin{array}{l}\text { Mengakhiri } \\
\text { pembelajaran }\end{array}$ & 4 & b, c dan d & 4 & $\mathrm{~b}, \mathrm{c}$ dan $\mathrm{d}$ \\
\hline & Jumlah Skor & 37 & & 36 & \\
\hline
\end{tabular}

Berdasarkan tabel di atas, dapat dilihat bahwa secara umum kegiatan siswa sudah sesuai harapan meskipun ada beberapa diskriptor yang tidak muncul dalam aktivitas siswa selama pembelajaran. Nilai yang diperoleh pengamat I adalah 37 dan nilai yang diperoleh dari pengamat II adalah 36, sedangkan nilai maksimalnya 45 .

Sehingga rata-rata nilai adalah $\frac{37+36}{2}=$ 36,5 . Jika nilai akhir prosentase yang didapat $\frac{36,5}{45} \times 100 \%=81,11 \% . \quad$ Sesuai $\quad$ taraf keberhasilan tindakan yang telah ditetapkan, yaitu:

a) $90 \%$ NR $100 \%$ : sangat baik

b) $80 \% \mathrm{~S} \mathrm{NR}<90 \%$ : baik

c) $70 \% \mathrm{NR}$ S80\%: cukup

d) $60 \%$ NRS $70 \%$ : kurang

e) $0 \%$ NR $60 \%$ : kurang sekali

Maka taraf keberhasilan aktivitas siswa berada pada kategori baik.

Tes akhir dalam penelitian ini dilakukan pada pertemuan kedua, yang berlangsung selama kurang \pm 10 menit. Kegiatan tes akhir ini diikuti oleh seluruh siswa kelas VIl-2 MTs Negeri BinjaI diperoleh data rata-rata nilai hasil belajar siswa adalah 69,25 dari nilai maksimal ideal 100. Siswa yang memperoleh ketuntasan individual atau yang mendapat nilai $\geq 80$ adalah sebanyak 15 orang dari jumlah 40 orang siswa atau $37,5 \%$. 
Sedangkan siswa yang belum mencapai ketuntasan belajar secara individual atau belum memperoleh nilai $\geq 80$ adalah sejumlah 25 siswa 40 orang siswa atau $62,5 \%$.

Dari data tersebut dapat disimpulkan bahwa telah terjadi peningkatan pemahaman dalam kemampuan kosa kata siswa. Hal ini dibuktikan dengan hasil belajar siswa pada rata-rata skor tes awal adalah 59,25, sedangkan rata-rata pada tes akhir siklus I meningkat menjadi 71,75 . Siswa yang berada pada taraf tuntas adalah 15 siswa, dan pada pre test hanya 12 siswa yang masuk kategori tuntas. Dengan demikian, untuk tindakan siklus kesatu ini, bisa dikatakan belum mencapai batas ketuntasan minimal kelas yaitu $\geq 75 \%$ siswa mencapai nilai $\geq 80$, atau dengan kata lain pada siklus I ini siswa kelas VII MT's Negeri Binjai secara klasikal belum mencapai ketuntasan kelas.

Berdasarkan kegiatan refleksi terhadap hasil tes akhir, hasil pengamatan dan hasil catatan lapangan pada siklus I, maka dapat diperoleh beberapa hal berikut:

1) Hasil belajar siswa berdasarkan skor tes akhir menunjukkan peningkatan yang cukup baik dari tes sebelumnya, hal ini menunjukkan bahwa pemahaman siswa terhadap materi pembelajaran semakin meningkat dan siswa merasa lebih senang.

2) Aktivitas peneliti telah menunjukkan tingkat keberhasilan pada kriteria baik. Oleh karena itu masih perlu pengulangan siklus untuk aktivitas peneliti selanjutnya supaya lebih baik. Peneliti perlu mengkondisikan agar lebih konsentrasi pada pembelajaran

3) Aktivitas siswa telah menunjukkan tingkat keberhasilan pada kriteria baik. Oleh karena itu masih perlu pengulangan siklus untuk aktivitas siswa selanjutnya agar lebih baik. Karena masih ada siswa yang kurang memperhatikan penjelasan peneliti, melainkan lebih asyik dengan dunianya sendiri, misalnya bermain, berbicara dengan temannya diluar materi, mencari perhatian peneliti dengan melakukan halhal yang tidak penting, dan lain sebagainya.

4) Kegiatan pembelajaran menggunakan waktu yang sudah sesuai rencana. Oleh sebab itu, tidak perlu diadakan pengulangan siklus untuk pengulangan waktu.

5) Kegiatan pembelajaran telah menunjukkan keaktifan siswa dalam kegiatan pembelajaran.

6) Meskipun rata-rata skor sudah mencapai target standar SKM, tetapi belum maksimal.

Dalam arti peneliti belum mencapai ketuntasan minimal kelas yaitu $\geq 75 \%$ siswa mencapai nilai $>70$. Terbukti dari hasil post tes siklus I bahwa siswa yang mengalami ketuntasan belajar sebanyak 12 siswa atau $70,59 \%$ sedangkan yang belum tuntas sebanyak 5 siswa atau 29,41\%. Jadi jelas perlu dilakukan siklus II untuk meningkatkan hasil belajar dan pemahaman.

\section{SIKLUS II}

Tabel 3. Hasil Pengamatan Aktivitas Peneliti pada Siklus II

\begin{tabular}{|c|c|c|c|c|c|}
\hline \multirow{2}{*}{ Tahap } & \multirow{2}{*}{ Indikator } & \multicolumn{2}{|c|}{ Pengamat I } & \multicolumn{2}{|c|}{ Pengamat II } \\
\hline & & Nilai & Deskriptor & Nilai & Deskriptor \\
\hline 1 & 2 & 3 & & 4 & \\
\hline \multirow{3}{*}{ Awal } & $\begin{array}{l}\text { Melakukan } \\
\text { aktifitas } \\
\text { keseharian }\end{array}$ & 5 & Semua & 5 & Semua \\
\hline & $\begin{array}{l}\text { Menyampaikan } \\
\text { tujuan } \\
\text { pembelajaran }\end{array}$ & 5 & Semua & 5 & semua \\
\hline & $\begin{array}{l}\text { Mengingatkan } \\
\text { pengetahuan awal }\end{array}$ & 5 & Semua & 4 & $\mathrm{~b}, \mathrm{c}$, dan $\mathrm{d}$ \\
\hline \multirow{4}{*}{ Inti } & $\begin{array}{l}\text { Menyampaikan } \\
\text { materi dan } \\
\text { pentingnya materi }\end{array}$ & 4 & $\mathrm{a}, \mathrm{c}$, dan $\mathrm{d}$ & 4 & $\mathrm{a}, \mathrm{c}$, dan $\mathrm{d}$ \\
\hline & $\begin{array}{l}\text { Melakukan listen } \\
\text { and repeat }\end{array}$ & 5 & Semua & 5 & Semua \\
\hline & $\begin{array}{l}\text { Menyediakan } \\
\text { sarana dan } \\
\text { prasarana }\end{array}$ & 5 & Semua & 5 & semua \\
\hline & $\begin{array}{l}\text { Meminta siswa } \\
\text { memahami tugas }\end{array}$ & 4 & $\mathrm{a}, \mathrm{c}$ dan $\mathrm{d}$ & 4 & $\mathrm{a}, \mathrm{c}$, dan $\mathrm{d}$ \\
\hline
\end{tabular}




\begin{tabular}{llllll}
\hline \multirow{2}{*}{$\begin{array}{l}\text { Akhi } \\
\mathrm{r}\end{array}$} & $\begin{array}{l}\text { Merespon } \\
\text { pembelajaran }\end{array}$ & 5 & Semua & 4 & $\mathrm{a}, \mathrm{b}$, dan c \\
\cline { 2 - 6 } & $\begin{array}{l}\text { Melakukan } \\
\text { evaluasi }\end{array}$ & 5 & Semua & 5 & semua \\
\cline { 2 - 6 } & $\begin{array}{l}\text { Mengakhiri } \\
\text { pembelajaran }\end{array}$ & 5 & Semua & 5 & semua \\
\hline & Jumlah Skor & $\mathbf{4 8}$ & & 46 & \\
\hline
\end{tabular}

Berdasarkan tabel di atas, ada beberapa hal yang tidak dilakukan peneliti

meskipun demikian secara umum kegiatan peneliti sudah sesuai rencana yang ditetapkan pada lembar observasi terscbut. Nilai yang diperoleh pengamat I adalah 48 dan nilai yang diperoleh dari pengamat 11 adalah 46 sedang nilai maksimal 50. Sehingga nta-rata nilai adalah $\frac{48+46}{2}=47$. Jika nilai akhir prosentase yang didapat adalah $\frac{47}{50} \times 100 \%=94 \%$. Sesuai taraf keberhasilan tindakan yang telah ditetapkan, yaitu :
a) $90 \% \mathrm{~S}$ NR S 100\%: sangat baik
b) $80 \%$ NR s $90 \%$ : baik
c) $70 \%$ NR $80 \%$ : cukup
d) $60 \%$ SNR S $70 \%$ : kurang
e) $0 \%$ NR $60 \%$ : kurang sekali

Maka taraf keberhasilan aktivitas peneliti berada pada kategori sangat baik.

Adapun hasil pengamatan yang dilakukan oleh kedua pengamat terhadap aktivitas siswa selama kegiatan pembelajaran pada siklus I dapat dilihat pada tabel berikut:

Tabel 4. Hasil Pengamatan Aktivitas Siswa Pada Siklus II

\begin{tabular}{|c|c|c|c|c|c|}
\hline \multirow{2}{*}{ Tahap } & \multirow{2}{*}{ Indikator } & \multicolumn{2}{|c|}{ Pengamat I } & \multicolumn{2}{|c|}{ Pengamat II } \\
\hline & & Nilai & Deskriptor & Nilai & Deskriptor \\
\hline 1 & 2 & 3 & & 4 & \\
\hline
\end{tabular}

\begin{tabular}{|c|c|c|c|c|c|}
\hline \multirow{3}{*}{ Awal } & $\begin{array}{l}\text { Melakukan aktifitas } \\
\text { keseharian }\end{array}$ & 5 & Semua & 5 & Semua \\
\hline & $\begin{array}{l}\text { Menyampaikan } \\
\text { tujuan pembelajaran }\end{array}$ & 4 & $\mathrm{a}, \mathrm{b}$, dan $\mathrm{d}$ & 4 & $\mathrm{a}, \mathrm{b}$, dan $\mathrm{c}$ \\
\hline & $\begin{array}{l}\text { Keterlibatan dalam } \\
\text { pembangkitan } \\
\text { pengetahuan awal }\end{array}$ & 4 & $\mathrm{a}, \mathrm{c}$, dan $\mathrm{d}$ & 4 & $\mathrm{a}, \mathrm{b}$ dan $\mathrm{c}$ \\
\hline \multirow{3}{*}{ Inti } & $\begin{array}{l}\text { Menyimak } \\
\text { penjelasan materi }\end{array}$ & 4 & $\mathrm{a}, \mathrm{b}$, dan d & 5 & Semua \\
\hline & $\begin{array}{l}\text { Keterlibatn dalam } \\
\text { listen and repeat }\end{array}$ & 5 & Semua & 5 & Semua \\
\hline & $\begin{array}{l}\text { Memanfaatkan } \\
\text { sarana dan prasarana } \\
\text { yang tersedia }\end{array}$ & 5 & Semua & 5 & Semua \\
\hline \multirow{4}{*}{ Akhir } & Merespon kegiatan & 4 & $\mathrm{a}, \mathrm{c}$, dan d & 3 & a, c dan d \\
\hline & Melakukan evaluasi & 5 & Semua & 5 & Semua \\
\hline & $\begin{array}{l}\text { Mengakhiri } \\
\text { pembelajaran }\end{array}$ & 5 & Semua & 5 & Semua \\
\hline & Jumlah Skor & 41 & & 42 & \\
\hline
\end{tabular}

Berdasarkan tabel di atas, dapat dilihat bahwa secara umum kegiatan siswa sudah sesuai harapan meskipun ada beberapa deskriptor yang tidak muncul dalam aktivitas siswa selama pembelajaran. Nilai yang diperoleh pengamat I adalah 41 dan nilai yang diperoleh dari pengamat II adalah 42, sedangkan nilai maksimalnya 45 .

Sehingga rata-rata nilai adalah $\frac{41+42}{2}=$ 41,5 . Jika nilai akhir prosentase yang didapat $\frac{41,5}{45} \times 100 \%=92,22 \%$. Sesuai taraf keberhasilan tindakan yang telah ditetapkan, yaitu:

a) $90 \% \mathrm{~S}$ NR S 100\%: sangat baik

b) $80 \%$ NR s $90 \%$ : baik

c) $70 \%$ NR $80 \%$ : cukup

d) $60 \%$ SNR S $70 \%$ : kurang

e) $0 \%$ NR $60 \%$ : kurang sekali

Maka taraf keberhasilan aktivitas peneliti berada pada kategori sangat baik.

Tes akhir dalam penelitian ini yang berlangsung selama \pm 10 menit diperoleh data rata-rata nilai hasil belajar siswa adalah 86,75 dari nilai maksimal ideal 100. Siswa yang memperoleh ketuntasan individual atau yang mendapat nilai $\geq 80$ adalah sebanyak 32 siswa 


\section{Jurnal Serunai Bahasa Inggris \\ Vol 12, No. 1, Maret 2020 \\ e-ISSN 2621-010X}

dari jumlah 40 orang atau $80 \%$, sedangkan siswa yang belum mencapai ketuntasan belajar secara individual atau belum memperoleh nilai 80 adalah sejumlah 12 orang dari 40 siswa atau $20 \%$.

Dari data tersebut dapat disimpulkan bahwa terjadi peningkatan pemahaman pada siswa. Hal ini dapat ditunjukkan melalui hasil tes akhir siswa, dari nilai rata-rata skor siklus I adalah 71,75 kemudian meningkat menjadi 88 pada nilai rata-rata skor akhir siklus IL. Selain itu, pada siklus kedua ini siswa juga telah berhasil mencapai batas ketuntasan minimal kelas yaitu $\geq 75 \%$ siswa mencapai nilai $\geq 80$. Dengan kata lain pada siklus II ini siswa kelas VIl-2 MTs Negeri Binjai secara klasikal mencapai ketuntasan belajar.

Pelaksanaan penelitian ini terdiri dari dua siklus tindakan, sedangkan kegiatan pembelajaran dari setiap siklus dalam penelitian ini terbagi pada tiga kegiatan, yaitu kegiatan awal, inti, dan akhir. Kegiatan awal dimaksudkan untuk mempersiapkan siswa baik fisik dan mental untuk menghadapi kegiatan inti. Siswa perlu dipersiapkan untuk belajar karena siswa yang siap untuk belajar akan belajar lebih banyak dari pada siswa yang tidak siap.

Berdasarkan hasil observasi yang dilalkukan oleh kolaborator peneliti, secara umum siklus I maupun siklus II terdapat peningkatan yang cukup signifikan.

Peningkatan tersebut dapat dilihat pada tabel 5 berikut:

Tabel 5. Peningkatan Aktivitas Peneliti dan Siswa Pada Siklus I dan Siklus II

\begin{tabular}{llll}
\hline & Siklus I & \multicolumn{2}{c}{ Siklus II } \\
\hline Aktivitas & Aktivitas & Aktivitas & Aktivitas \\
Peneliti & Siswa & Peneliti & Siswa \\
\hline $83 \%$ & $81,11 \%$ & $94 \%$ & $92,22 \%$ \\
\hline
\end{tabular}

Peningkatan aktivitas peneliti ini menunjukkan bahwa peneliti sudah mempersiapkan secara matang dan terencana, sedangkan peningkatan aktivitas siswa menunjukkan bahwa siswa sangat antusias dalam proses pembelajaran dengan menggunakan media gambar, sehingga ada motivasi dan semangat untuk belajar. Peningkatan juga terjadi pada hasil tes akhir siswa ditiap siklus yang disiaplkan oleh peneliti yang menunjukkan adanya perubahan positif. Hal iní dapat dilihat pada tabel berikut:

Tabel 6. Peningkatan Hasil Tes Akhir Siswa Pada Siklus I dan Siklus II

\begin{tabular}{llll}
\hline Kriteria & $\begin{array}{l}\text { Tes } \\
\text { Siklus I }\end{array}$ & $\begin{array}{l}\text { Tes } \\
\text { Siklus II }\end{array}$ & Peningkatan \\
\hline $\begin{array}{l}\text { Rata-rata tes } \\
\text { akhir siswa }\end{array}$ & 71,75 & 88 & 16,25 \\
\hline $\begin{array}{l}\text { Ketuntasan } \\
\text { belajar siswa }\end{array}$ & $37,5 \%$ & $80 \%$ & $42,5 \%$ \\
\hline
\end{tabular}

Dari tabel diatas dapat diketahui bahwa rata-rata hasil belajar siswa mengalami peningkatan. Rata-rata hasil belajar siswa pada tes siklus I sebesar 71,75, sedangkan rata-rata hasil belajar siswa pada tes siklus II adalah 88, dan terjadi peningkatan sebesar 16,25. Begitupun juga dengan ketuntasan belajar siswa yang mengalami peningkatan hingga $42,5 \%$, dengan rincian ketuntasan belajar siswa pada siklus I adalah 37,5\% dan ketuntasan belajar siswa pada siklus II adalah $80 \%$. Berdasarkan paparan data di atas dapat disimpulkan bahwa dengan meningkatnya aktivitas peneliti dalam menerapkan penggunaan media gambar dari siklus I ke siklus II dan kegiatan aktivitas siswa dari siklus 1 ke siklus II maka menjadikan kemampuan kosa kata Bahasa Inggris siswa mengalami peningkatan. Hal ini menunjukkan penerapan model pembelajaran Think Pair Share dapat meningkatkan kemampuan Bahasa Inggris siswa kelas kelas VIl MTs Negeri Binjai. 


\section{KESIMPULAN}

1. Penerapan Model Pembelajaran Think Pair Share dalam pembelajaran dapat meningkatkan kemampuan belajar Bahasa Inggris siswa. Hal ini dibuktikan dengan peningkatan hasil belajar siswa yang cukup memuaskan pada tiap siklusnya.

2. Melalui proses pembelajaran seperti halnya di atas maka membuat siswa merasa senang dengan pembelajaran tersebut karena selain bisa meningkatkan pemahaman terhadap materi, meningkatkan kemampuan kosa kata, juga dapat meningkatkan keaktifan, antusias, dan perhatian siswa dalam belajar.

3. Penerapan Model Pembelajaran Think Pair Share ini bisa menjadi salah satu altenatif bagi guru dalam mengajar, terutama untuk mata pelajaran Bahasa Inggris.

\section{DAFTAR PUSTAKA}

Asvad, Azhar, Media Pembelajaran, Jakarta: PT Raja Grafindo Persada, 2008.

Arikunto, Suharsimi, Prosedur Penelitian Suatu Pendekatan Praktik, Jakarta: Bina Aksara, 1989. , Prosedur penelitian Suatu Pendekaan Praktek, Jakarta Rineka Cipta, 1993. et. all., Penelitian Tindakan Kelas, Jakarta: PT Bumi Aksara, 2010.

Asnawir dan Basyirudin Usman, Media Pembelajaran, Jakarta: Ciputat Press, 2002.

B. Miles Matthew dan Michael Huberman, Analisis Data Kualiatif, Tetj. Eyep Rohendi, UI-PRESS, 1992.

Fajri, FM Zul, Kamus Lengkap Bahasa Indonesia, Jakarta: Difa Publisher, t.t.
Hamalik, Oemar, Media Pendidikan, Bandung: Citra Aditiya Bakti, 1989

,Teknik Pengukur Dan Evalusi Pendidikan, Bandung: Mandar Maju, 1989.

Media Pendidikan, Bandung: Citra Aditya Bakti, 1994.

Harjanto, Perencanaan Pengajaran, Jakarta: PT Rineka Cipta, 2006.

Hasan, Muhammad Tholchah et. all, Metodologi Penelitian Kualitatif, Malang. LPUIM, 2003.

Kunandar, Guru Profesional Implementasi Kurikulum Tingkat Satuan Pendidikan (KTSP), Jakarta: PT RajaGrafindo, 2009.

Moleong, Lexy J., Metodologi Penelitian Kualitatif, Bandung: PT Remaja Rosdakarya, 2008.

Muallifah, Ilun et. all., Perkembangan Peserta Didik Edisi Pertama, ttp: tp, 2008.

Mulyasa, E., Kurikulum Berbasis Kompetensi, Bandung: Remaja Rosdakarya, 2006.

Praktik Penelitian Tidakan

Kelas, Bandung: PT Remaja Rosdakarya, 2009.

Naim, Ngainun, Menjadi Guru Inspiratif Memberdayakan dan Mengubah Jalan Hidup Siswa, Yogyakarta: Pustaka Pelajar, 2009.

Nazir, Moh., Metode Penelitian, Jakarta: Ghalía Indonesia, 1988.

Purwanto Ngalim, Prinsip-prinsip dan Teknik Evaluasi Pengajaran, Bandung: Remaja Rosdakarya, 2004. 
Pusat Bahasa Departemen Pendidikan Nasional, Kamus Besar Bahasa Indonesia Edisi Ketiga, Jakarta: Balai Pustaka, t.t.

R.Ibrahim \& Nana Syaodah S., Perencanaan Pengajaran, Jakarta: PT Rineka Cipta, 2010.

Rohani, Ahmad, Media Intruksional Edukatif, Jakarta: PT Rineka Cipta, 1997.

Sadiman, Arief S. et. all., Media Pendidikan Pengertian, Pengembangan. Dan Pemanfaatannya, Jakarta: PT Rajagrafindo Persada, 2008.

\section{Media Pendidikan}

Pengertian, Pengembangan, dan Pemanfaatannya, Jakarta: PT Raja Grafindo, 2009.

Saiful Bahri Djamarah dan Aswan Zain, Strategi Belajar Mengajar, Jakarta: Rineka Cipta, 2002.

Sukmadinata, Nana Syaodih, Landasan Psikologzi Proses Pendidikan, Bandung: PT Remaja Rosdakarya, 2009.

Sanjaya, Wina, Perencanaan dan Desain Sistem Pembelajaran, Jakarta: Kencana, 2009.
Siswono, Tatag Yuli Eko, Mengajar dan Meneliti: Panduan Penilitian Tindakan Kelas untuk Guru dan Calon Guru, Surabaya: UNESA University Press, 2008.

Sudjana, Nana, Penilaian Hasil Proses Belajar Mengajar, Bandung: PT Remaja Rosdakarya, 2005.

Sukardi, Metodologi Penelitian Pendidikan: Kompetensi dan Praktiknya, Jakarta: PT Bumi Aksara, 2007.

Suyanto, Kasihani K.E., English For Young Learners, Jakarta: Bumi Aksara, 2007.

Usman, Moh Uzer, Menjadi Guru Profesional Edisi Kedua, Bandung: PT Remaja Rosdakarya, 2008.

UU RI No. 20 Tahun 2003, Sistem Pendidikan Nasional, Jakarta: Sinar Grafika, 2008.

W., Sri Anitah, et all., Materi Pokok Strategi Pembelajaran SD, Jakarta: Universitas Terbuka, 2007

Wiriatmadja, Rochiati, Metodologi Penelitian Tindakan Kelas Untuk Meningkatkan Kinerja Guru dan Dosen, Bandung PT Remaja Rosdakarya, 2005. 